\title{
Health Service Information System in Kendal District toward Kendal Smart City
}

\author{
Siti Musyarofah ${ }^{1}$, Ratna Muliawati ${ }^{1}$, Mushidah $^{1}$ \\ \{ sitimusyarofah24@gmail.com,r.moelia@gmail.com, hidnisa4@gmail.com\} \\ ${ }^{1}$ Public Health Program of Study, Kendal college of Health Sciences, Indonesia, 51311, \\ Kendal
}

\begin{abstract}
A good information system can provide accessible health services, which can be the basis of health service management in determining policies. Smart city has been implemented in several cities; one of which is Kendal. Smart city in the field of health services includes several indicators; one of them is the health information system used. Using a descriptive study design, this research aimed to describe the health services information system in Kendal toward Kendal smart city. It was conducted in district health office and ten health services were taken by purposive sampling method. The research respondents were stakeholders of the information system and patients who visited the health office. Data were collected using in-depth interview and observation. The data were then analyzed by data reduction. The results showed that the health service information system used by the district health office and hospital was a self-developed system. In public health center, they used SIMPUS, which is provided by the district health office. In Clinic, computerized and manual systems were used. The obstacles are data processing and fulfillment of human resources. The government should provide information systems that are in accordance with whose needs, make rules about the single data system, and meet human resources needs.
\end{abstract}

Keywords: Information system, health service, smart city, Kendal

\section{Introduction}

Efforts to achieve the SDG objectives must go hand in hand with plans for economic growth and address various social issues including health, education, climate change and inequality. Conventional solutions cannot solve the increasingly complex city problems. Therefore, a smart solution is needed, namely smart city. [1]. 
The term "Smart City" has been popular in the community, both through print and social media [2]. Smart city is defined as a city that is able to use human resources, social capital, and modern telecommunications infrastructure to realize sustainable economic growth and high quality of life, with wise resource management through community participation-based governance [1]. Smart city is also defined as a city that can manage its various resources effectively and efficiently to solve various city challenges using innovative, integrated and sustainable solutions to provide infrastructure and city services that can improve the quality of life of community [3]. Smart city is a city that utilizes information technology to integrate all infrastructure and services from the government to the community, such as administration, education, health, transportation, economy, energy resources, settlement and public safety. By synergizing all these aspects with the community, smart city will be able to improve city development and management [2].

Solutions must be integrated between institutions/ministries/offices. The solutions must also be integrated with the non-government field. Integration includes business processes, data and applications. A health service network in a city/district must be available. Every district/city must have a health service network. The service must be able to connect, monitor, and control decision making from each network of health service units [3].

The development of cities toward smart city concept begins with the use of information and communication technology on priority issues, which is usually partial[2]. Kendal district launched three applications in November 2018 to support Kendal smart city. These three applications will be integrated directly with public services, so that people can easily acces and know all the services of Kendal district government. Three service applications were the "Poskamling Pintar, PSC 119 Health Service, and the complaints of district communication and information agency [4].

Research on health service information systems needs to be carried out in Kendal district to investigate how the health service information system runs. Health services which become the subject of research are both government and private health services. The results of the study are expected to be the basis for the development of health services in Kendal city.

We must continue to improve synergy with industry and community, so that science and technology and innovation contribute maximally to the development of the nation and address the nation's problems. In this case, the researchers synergized the needs of the study by conducting basic research as a basis for health policy making in relation to the development of health care information systems. It is expected that the results of this study can be the basis for the development of a health service information system so that the data becomes one unit. Whenever members of the local community needs treatment or health services, the health service information system can be accesed from anywhere. Ease of access to health services, both primary, secondary and tertiary. Thus, the community can be satisfied with the health service facilities in Kendal district and a healthy and independent society can be realized.

\section{Method}

This research is a descriptive study with qualitative approach. The study population included all health services in Kendal district. The research sample is health services in Kendal district. The sampling technique used was purposive sampling.

The health services studied were in Kendal district, which included district health offices, 1 regional public hospital (RSUD Dr.H. Soewondo Kendal), and all private hospitals in Kendal (RSI Kendal, RS Baitul Hikmah, and RS Darul Istiqomah). There are several clinics in Kendal district; two private clinics are selected as samples, Assalamah and Dr.Nur Rochim clinic. In Kendal district, there were 31 Puskesmas; 2 samples were selected, which were Rowosari II Puskesmas and Kaliwungu Puskesmas. In addition, the study sample included health services owned by the health office, namely Griya Sehat and PSC 119 SIAGA Kendal district. The total research locations were 11 research sites. 
Research respondents were agency stakeholders, surveillance operators/personnels managing data, and patients visiting health services. The researchers also observed information systems used by health services. The researchers used interviews and observations obtain data about the health service information system. Health information system components are data, information, indicators, procedures, tools, and technology. Human resources are clearly illustrated in each health service using both methods. Data collection was done using the interview guidelines and checklist.

The first research stage was preparation. The researchers prepared the research needs including tools and research support. Then, the researchers obtained approval for conducting the research from the office of KESBANGPOL, BAPERLITBANG, Health service, Hospitals, Puskesmas, and clinics in Kendal district. In the next stage, the researchers interviewed the stakeholders, surveillance personnel/information system operators, and patients who visited the health centers. The researcher observed and interviewed the participants regarding the health service information system that was used by the health service. Then, the data were analyzed by triangulation. How is health information system according to stakeholders, implementer and from users, that is community.

\section{Result}

Due to limited human resources in the hospitals and health centers, not all participants could be interviewed. The Stakeholders of information system sometimes also act as implementers and are responsible for the information system. One participant was interviewed, supported by observation of information systems and patients who visited the health center. in Table 1.

There are health service information system components in 11 research locations as shown

\begin{tabular}{|c|c|c|c|c|c|c|c|c|}
\hline NO & $\begin{array}{l}\text { Health } \\
\text { Service }\end{array}$ & Data & Information & Indikator & Procedur & Devices & Technology & $\begin{array}{l}\text { Human } \\
\text { Resources }\end{array}$ \\
\hline 1 & $\begin{array}{l}\text { Health } \\
\text { Office }\end{array}$ & Available & Available & Available & Available & Available & Available & Less \\
\hline 2 & $\begin{array}{c}\text { Health } \\
\text { service } 1\end{array}$ & Available & Available & Available & Available & Available & Available & Less \\
\hline 3 & $\begin{array}{c}\text { Health } \\
\text { service } 2\end{array}$ & Available & Available & Available & Available & Available & Available & Fulfilled \\
\hline 4 & Hospital 1 & Available & Available & Available & Available & Available & Available & Enough \\
\hline 5 & Hospital 2 & Available & Available & Available & Available & Available & Available & Enough \\
\hline 6 & Hospital 3 & Available & Available & Available & Available & Available & Available & Less \\
\hline 7 & Hospital 4 & Available & Available & Available & Available & Available & Available & Less \\
\hline 8 & $\begin{array}{c}\text { Community } \\
\text { health center } \\
1\end{array}$ & Available & Available & Available & Available & Available & Available & Enough \\
\hline 9 & $\begin{array}{l}\text { Community } \\
\text { health center } \\
2\end{array}$ & Available & Available & Available & Available & Available & Available & Enough \\
\hline 10 & Clinic 1 & Available & Available & Available & Available & Available & Available & Enough \\
\hline 11 & Clinic 2 & Available & Available & $\begin{array}{c}\text { Not } \\
\text { available }\end{array}$ & Available & Not available & Not available & Enough \\
\hline & TOTAL & $\begin{array}{c}100 \% \\
\text { Available }\end{array}$ & $\begin{array}{c}100 \% \\
\text { Available }\end{array}$ & $\begin{array}{c}90,9 \% \\
\text { Available } \\
9,1 \% \text { Not } \\
\text { available }\end{array}$ & $\begin{array}{c}100 \% \\
\text { Available }\end{array}$ & $\begin{array}{l}90,9 \% \\
\text { Available } \\
9,1 \% \text { Not } \\
\text { available }\end{array}$ & $\begin{array}{l}90,9 \% \\
\text { Available } \\
9,1 \% \text { Not } \\
\text { available }\end{array}$ & $\begin{array}{c}36,4 \% \text { Less } \\
54,5 \% \\
\text { Enough } \\
9,1 \% \\
\text { Fulfilled }\end{array}$ \\
\hline
\end{tabular}

The results of interviews and observations are as follows:

\section{Health Office}


The health office has Health Center Information System (SIP) application, PSC 119, and health data dashboard. ASPAK and program information systems (diseases, nutrition, surveillance, and other information systems facilitated by the Ministry of health) are held directly by the program holders and directly input data, not integrated with the Sistem Informasi Puskesmas application. The Sistem Informasi Puskesmas is also not connected to SIM RS (hospital management and information system). SIP has the same flow as generic SIKDA, which contains monthly reports from Puskesmas. Generic SIKDA was not used because it is incomplete.

The health office did not have IT staff, but has an IT consultant (external staff) from Semarang health office.There is no organizational structure specifically for information systems. It is managed by the financial planning department. Budget support for the development of information systems was still minimal. The server used is still minimal and does not have its own server. The health office did not have a special computer for data processing but there is available dashboard. Each room has a printer.

In relation to policies, there is no roadmap from the regulation regarding the application of information systems. There is only a roadmap from the ministry of health. The financial reporting form already exists, operational already exists, the strategic plan also already exists. The healh office received manual reports from the hospitals, pharmaceutical warehouse, and private clinics in the form of visit reports and disease reports. Some hospitals have SIM RS, but they are not yet integrated with the health office.

Perceived obstacles are the central information system are still not integrated, each program has its own system, so there is still double data. Target in 2020, there are Puskesmas that have done online services. Since August 2019, the Puskesmas has run an information system on patient registration. Some Puskesmas have implemented SIP well. The health office also routinely conducts information system training/socialization every year with Puskesmas.

\section{Health service 1}

Griya Sehat and PSC 119 SIAGA Kendal district are health service providers under the management of the district health office. Data recording in the traditional health service (Griya Sehat) used a manual system, from the process of registration, service, to recording of the medical history. Information system for purchasing herbal medicine is online through SI JA-E LILA (Electronic Herbal medicine system for service-based research): www.sijae.org. The number of visits is relatively small ( 1 until 2 patient/day) because people want an instant healing process. The majority of community still holds the idea that when they seek treatment, they must recover quickly, while the healing process through herbal medicines in a healthy home cannot be instant, requiring relatively long process. In addition, the absence of doctors also becomes one of the obstacles. When the patient arrived, the register must contact the doctor first. Doctors and traditional health services are doctors of Puskesmas that have been certified in terms of herbal medicine. There is a doctor's picket schedule. The waiting time for the doctor is around 15 minutes.

\section{Health service 2}

PSC 119 SIAGA Kendal District is an emergency service connected to the nearest health service in Kendal district. That is the innovation in Kendal Smart City in the health sector. PSC 119 health service information system is an emergency service providing first aid (Firs Aid in Accident) and free ambulance services. This application provides information on the availability of rooms in the health services, blood availability at PMI (Indonesian Red Cross), and health information. Applications can be downloaded at playstore. For activating the application in playstore, GPS must be turned on. The application will show the position of the android holder who used the PSC 119 SIAGA Kendal District application. There are three menus: report an accident, report a crime, and report a fire. Contact the clerk to connect the phone and whatsapp. Call the three choices: Telkomsel, free call, and local telephone.

The menu of "Health Service" will provide information on the health services nearest to the android reporter/holder/patient who will visit. Health service consists of Puskesmas and hospitals. Once clicked, there will be a phone or WA menu. Automatically, it will be connected to the nearest health service to get emergency health services. 
All health services in Kendal district are integrated with PSC 119. Temporarily integrated only for information on room availability in health services, because only three from four health services. All puskesmas rarely update their data. For solve that, information will obtained by contact directly the nearest health service by phone, due to limited human resources in the health service to update the data.

\section{Hospital 1}

In regional general hospital in Kendal district, namely RSUD Dr.H.Soewondo. Kendal Regency, the Information system was built by the hospital. The hospital information system consists of 20 modules (registration, emergency services, outpatient, inpatient, support, payment, reporting/accounting, warehouse logistics, medical records, pharmacy, etc). The hospital also runs information systems from other agencies (BPJS and the health office), such as SIRANAP,ASPAK and online hospital (RL report), as well as application for bed availability. This information system is considered to have met the minimum requirements of the ministry of health. BPJS patient registration system is online, through WA, and based on android. Android -based registration is rarely used because patients prefer registration by WA. Hospitals do not run SIM RS GOS provided by the Ministry of Health because the ceiling provided is not accordance with the needs of the hospital. Registration for general patients still uses manual system. Inpatient availability information systems and medical record systems are run online using a LAN network through the website.

The information system of RSUD Dr.H.Soewondo Kabupaten Kendal consists of 8 technical staff ( 3 programmers, 5 hardware and network officers. They work in shift). This number of human resources is in accordance with standards based on workload analysis. There are no special operators/officers in each installation of RSUD. This is an obstacle especially for the problem of timeliness of data entry, so it is not real time. The problem of innacurate time entry emerges in emergency room when the number of patients is large. Nurses prioritize service to patients, and only enter data when the patient was treated. One of the obstacles is old medical record officers who feel burdened because they have to learn adapt to technology.

Support from hospital management is good in terms of providing infrastructure that supports information systems. RSUD has 9 servers. A special budget is available for the maintenance of information systems. Facilities/infrastructure already exist in the form of computer hardware in each installation room. Software is always developed to adjust with the needs. SIRANAP uses LAN. The hospital has a high dependency on the system (24 hours) so that if there is a power is off, it can become an obstacle. The hospital has back up power. The recording system RL1-RL5 has also been implemented online. The specific service information system from the government is managed by RSUD programmers team.

\section{Hospital 2}

The hospital already has an information system, called SIMRSMU which is integrated with the website "rsimuhkendal.com". The hospital information system is partly run electronically and manually. Online registration is provided by the menu on the website but it is still resctricted by the public IP so it cannot be run. The new information system was upgraded in 2013 to prepare BPJS, according to the development prototype. Obstacles faced in the implementation of information system are human resources. There is no operator or special officer for data entry. The hospital has not run an online medical record either because of lack of human resource. Doctors are not willing to input data. RL 1-RL5 recording system has been done online. Information system for inpatient rooms availability is provided through an integrated emergency management system (SPGDT) which can be accessed through yankes.kemkes.go.id, integrated PSC 119 SIAGA Kendal district.

6. Hospital 3 
Hospital 3 has an information system (SIMRS) using PHP. The initial system was developed by a third party, and then starting in 2016 it was developed by the hospital. The hospital has 1 IT staff (education background at Information technology). Hospital management supports the developedment of sistem information through the provision of budgets. However, the hospital still has a concern for the development of services through the system, especially those related to informed concent. The hospital has provided an online medical record module, but is not been run optimally due to user/operator limitations that input data. Online registration by WA, or by telephone. The hospital has made an application for online registration but has not yet launched, it is still in the evaluation stage of the management. The hospital has not collaborated eith BPJS.

\section{Hospital 4}

The information system used in a grant from RSI Kendal. The system is still manual. Registration is manual and can be through by WA. The obstacle still faced is the lack of human resources, especially for operators. In addition, there are still cases of double input such as room availability data, Operator have to input on the hospital database and input data to be reported on SIAGA 119. Human resources consist of 2 IT staff (D3 graduated)

\section{Community health center 1}

Puskesmas use the Sistem Informasi Puskesmas (SIP) that is reported systematically to the health office. Not all program holders input data in SIP because the majority of program holders are old and thus need an adaptation process with technology. The obstacle felt by Puskesmas when there is an error the entry cannot be edited but must be repeated from the beginning. SIP per individual, not for family folder, so that repeat the same data input. In 2020 it is hoped that the SIP will be routinely input because in the next, patient claims will be made through the system.

\section{Community health center 2}

The Puskesmas uses the SIP that was reported systematically to the district health office since June 2019 because it had received training from the health office. The Puskesmas has conducted socialization activities to all program holders, but the program holders have not all conducted data input in SIP due to human resource capabilities, especially for elderly program holder. Another obstacle felt by the puskesms is the slow loading system, and when there is an error the entry cannot be edited but must be repeated. Puskesmas have 1 IT coordinator whose job is to monitor the SIP report every month. Not all program holders report monthly acivities at SIP. The IT coordinator also cannot input program data because the program holder doesn't submit monthly report files. The IT coordinator officer also doubles as an officers at the registration window. In 2020 patient claims through SIP data, we hope that data from now on can already be rountinely inputted.

\section{Clinic 1}

Clinic 1 doesn't have an information system application yet. The registration process is still using manual system. Registration, services, up to billing/payment have been integrated using a computer system. Human resouces consist of 10 person, they are 1 doctor, 1 doctor obstetrician, 4 nurses (Diploma 3), 1 pharmaceutical staff, and 3 midwives. There is no data sent or integrated with the health office or hospital.

\section{Clinic 2}

The clinic 2 doesn't yet have a computerized information system. The recording system is manually, from patient registration to billing. Human resources in this clinic consist of 2 doctor, and 4 nurses.

\section{Discussion}


There is no specific application that integrates all health services in Kendal district. Application that integrates all health services in Kendal district while PSC 119 SIAGA Kendal District. This application is an emergency service, which provides information on room availability in all health services in Kendal district. Information on the availability of room space also has a problem, that is limited human resources in health services, because only hospitals regularly update data. From 4 hospital, 3 hospitals have been updating regularly. Solution to get information on room health services that are not updated by contact directly on the contact that can be clicked directly on the application menu.

Although Kendal district has not yet implemented e-health, it has begun to innovate in the field of health services, starting with emergency services with PSC 119 SIAGA. PSC 119 alert still needs to be socialized, because not all segments of the community know it. Hope in future for the establishment of smart city, services can be carried o, and police. But in one roof that is integrated in a system with the manpower and tansmigration, civil report. So that in the future the hospital can printbirth certificates and/or death certificates. Where NIK (Nomor induk Kependudukan) can be used in various services in Kendal district.

In the era of globalization, public service innovation using information technology is needed. All aspects of life depend on the digitization system. With digitalization it makes things efficient, effentive and pratical [5]. In Kendal, one day a trial was carried out for one door service. In Surabaya Single Window (SSW) has been implemented for various types of services. E-Health for health administration such as hospitals and puskesmas, and eLampid for population administration management such as birth and death certificat [6]. In Brazil also trying make application system mobile-based to support community health has health has surged in popularity[7].

e-Health, an application where community can register for treatment by online at the Puskesmas and government general hospital, so there is no need to queque for long at service counter[6]. Health services in Kendal district have improved their service systems. Registration that makes it easy for patients not be to too queued,. Registration can be via online, via WA, telephone, or register manually directly. Before improvement of the patient's health care information system was very full in the waiting room and had to wait for hour in previous year. Now with improvement of the health service information system, people don't need to be too queued to get services.

Concerns from private hospitals in Kendal have to do with data security if all systems are already running online. E-Health is included in the policy innovation, because after online patient registration through e-Health services, the authority over NIK servers and data is owned by Dinas Komunikasi dan Informasi dan Dinas Kependudukan dan Catatan Sipil, health services are the executingparties in the running of e-health services themselves. Where before these service appeared, the authority to manually register patients was exercised by the health service. E-health is also included in the systeminnovation, because with the e-health Puskesmas information syste is online [6]. In an integrated health service information system requires regulations or regional regulations or legal umbrella that includes the district information system and health services that are accompanied by data and information security. As proposed by the city of Pekalongan in integrating health service data [8].

Information systems in hospitals are not an obstacle in Kendal district. Each hospital has data, health office just do bridging data. For SIP that have started running online in 2019, application have been prepared from the health service in the form of SIP. In 2020 the Puskesmas is required to be $100 \%$ complete for data entry. This is also an effort to improve service quality, by preparing for the integration of health data in Kendal district. This situation is also the same as in other regions, in the Depok public health center. Depok Government to improve service quality by implementing SIMPUS. SIMPUS can provide satisfication to the community in the speed, accuracy, and accountability of services [9].

The health service information system in the sample clinic still uses manuals and simple information with a comuter. Not using a special application and that can be hybridized. This situation is also the same as the information system at the permata medica center Pati Clinic which initially carried out a variety of operational activities that collect, store and process data, all of which are still done manually. Then the clinic management information system is applied [10]. 
The health information systems, the component is a a set arrangements that include data, information, indicators, procedures, tools, technology, and human resources that are interrelated and managed in an integrated manner to direct actions or decisions that are useful in supporting health development[11]. All components have been fulfilled. Only the human resource component remains an obstacle in Kendal district. As stated in Table 1, where is human resources 36,4\% Less; 54,5\% Enough and just 9,1\% Fulfilled.

Regulation of the Ministry of Health of Republic Indonesia number 97 of 2015 concerning health information system roadmap for 2015-2019. There are the regulations concerning district/city governments have the authority to manage and develop district/city scale health information systems [12]. The Health office in Kendal already has a SIP application to support regional health information systems. However, the regional health information system has not been integrated with SIM RS, this related to the limited human resources of the health service, there is no official who verifies it.

Health information systems (HIS) effectively reduce cost in health care delivery and medical error, and increase clinicians' productivity [13]. This was also felt by the research site. The information system that is run makes it easier in hospital management, but human resources are still limited. Medical personnel such as nurses do not want to input medical report data when services are performed.

Government policies on the development of information system already exist, but in its implementation, there are still many obstacles. The developed health information systems both central and regional levels cannot be fully utilized due to limitations of system being developed, reginal capabilities, and human resources[14]. According to information from informants "There is no roadmap of local regulations regarding the application oh information systems. There is only a roadmap from the ministry oh Health. In the strategic plan, the health deprtment has included it".

"The problem felt by the central information system are still not integrated, each program has its own system so there is still double data". We hoped that the central government will not make their own applications, for the example TB reportingproblems, TB officer must have to input data in the SITT application and SIP. This has become less effective. The SIM GOS RS application, SIKDA Generic offered by the government is not yet in accordance eith regioanal need, and the price is to hight.1

In principle, the application system in the main unit must be able to communicate with the integration applications in the data and information Center (data communication and data warehouse). However, this is still not optimal because it is still at the coordination stage of integration development. In addition, mechanisms/procedures related to one-door information are not yet available., this is a cause of data duplication and is one of the factors in the difficulty of building health information systems in regions that are will integrated with national health information sistems [12].

The district health office has the task of managing data and information obtained from Puskesmas, hospitals and other health service facilities. In this regard, the city or district health office needs a good management of the health information system so that government policy decisions can be more appropriate according to the needa of the region[14]. Kendal health office requires regional regulations, fufillment of human resources, and joint commitment to data integration.

The location of research which is ready to support smart city is the regional public hospital (RSUD). However, the menu provided by health office is very simple. Hospital is ready for data if the health office or government request data. RSUD is ready for bridging data RSUD has implemented online services. There are 20 modules in the information systems. Inpatient e-RM has been run, outpatient e-RM has begun to be used, room availability data has also been connected with PSC alert 119 and the RSUD website. Application for bed availability. This information system is considered have met the minimum requirements of the Ministry of Health. However, in the implementation of human resources special officers in the service that do not input data yet. The work is still inputted by nurses, so it is less than optimal because of double task. 
Some obstacles related to human resources become almost the same picture both at central and regional levels. The quantity and quality human resources still do not meet the needs. The ability to conduct management and analysis of health data is still lacking[12]. The situation in Kendal district is in accordance with research conducted in 2016 in the central java provincial health office, indicating that the quality of human resources in information system in Central Java Province is still low. This is due to the low appreciation of the importance of information so that the human resources assigned to SIK (Sistem Informasi Kesehatan) do not have capacity. PP46 concerning SIK article 51 paragraph (2) states that human resources that manage SIK must have competence in the fields of statistics, computers, and epidemiology[15]. Human resources in Kendal District hospitals and health services are in accordance with competencies, while in the health department is limited in quantity. For officers in the Puskesmas is still not according to competence. Whereas in clinic not realizing the importance of information systems, human resources still limited.

\section{Conclusion}

In general, the description of information systems that are running at this time is still fragmented. Each program has a database that stand alone. This has implications for the difficulty of meeting the needs of composite information that must correlate two or more databases. In addition, to the problem of data integrity that can occur, this condition results in a higher administrative burden ratio in health service facilities. This will indirectly have an impact on the disruption of the performance of public services. Difficult acces to data on systems that are not integrated will be an obstacle in providing information so that evidencebased management of public health programs is difficult[12]. How to make an information system can improve the performance of health services and how to present a system that provides information quickly and accurately to the district health office we must know [16].

It is hoped that the community can take advantage of health service applications that are available in Kendal district, namely PSC 119 SIAGA Kendal district and Griya Sehat (traditional treatment). Local government can socialize PSC 119 alert and traditional health services to all elements of the community. Local government need to make regulations on health information systems that are integrated with services in the district. In addition, the government should provide information system that are in accordance with needs, make rules about the single data system, and to meet the quantity shortage of human resources, it is necessary to add human resources in health services (meet human resources needs), to improve human resources compentency needs to be done periodic staff capacity building training. Private clinic must to implement the same information system as the government, so that the data becomes one unit.

In addition, the government should provide information systems that are in accordance with needs, make rules about the single data system, and to meet the quantity shortage of human resources, it is necessary to add HR in health services (meet human resources needs), to improve HR competency needs to be done periodic staff capacity building training. Private clinics are expected to implement the same information system as the government, so that the data becomes one unit.

\section{Acknowledgements.}

The author would like to thank the Directorate of Research and Community Services, the Directorate General of Research and Development of the Indonesian Ministry of Research, Technology, and Higher Education which has funded the research activities. She also thanks the health services in Kendal district and the research participants.

\section{References}

[1] V. Rosalina, Y. Sugiyani, and A. Triayudi, "Perancangan Infrastruktur Jaringan Komputer dalam Konsep Membangun Serang Menuju Smart City," J. PROSISKO, vol. 1, no. September, pp. 2-5, 2014.

[2] S. Esabella, "Menuju Konsep Smart City," 2018. [Online]. Available: www.researchgate.net/publication/323303099. 
[3] S. H. Supangkat, "Smart City and Smart Health." Asosiasi Prakarsa Indonesia Cerdas (APIC), 2017.

[4] R. M. Jateng, "Tiga Aplikasi Andalan 'Kendal Smart City,” Metro jateng 2018. [Online]. Available: metrojateng.com/tiga-aplikasi-andalan-kendal-smart-city/.

[5] R. D. P. Meyliano, "Inovasi Pelayanan Publik di Era Disrupsi (Studi tentang Keberlanjutan Inovasi E-Health di Kota Surabaya)," J. Chem. Inf. Model., vol. 53, no. 9, pp. 1689-1699, 2015.

[6] D. A. Hafizh, "Studi Deskriptif tentang Penerapan Layanan e-Health dalam meningkatkan Kualitas Pelayanan Kesehatan di Puskesmas Pucangsewu Kota Surabaya," vol. 4, 2016.

[7] J. V Rajan, J. Moura, G. Gourley, K. Kiso, A. Sizilio, A. M. Cortez, L. W. Riley, M. A. Veras, and U. Sarkar, "Understanding the barriers to successful adoption and use of a mobile health information system in a community health center in São Paulo, Brazil : a cohort study," BMC Med. Inform. Decis. Mak., pp. 1-12, 2016.

[8] E. B. Susanto, M. F. Kurniawan, P. A. Christianto, P. Studi, and T. Informatika, "Integrasi Informasi Kesehatan Pada Instansi Kesehatan di Kota Pekalongan,” vol. 13, pp. 31-39, 2017.

[9] N. Handayani and Izzatusholekha, "Penerapan sistem informasi manajemen puskesmas (simpus) dalam meningkatkan pelayanan di puskesmas sawangan, depok 1,2," no. 511, pp. 161-170, 2014.

[10] M. P. Kumara, A. P. Utomo, and F. Nugraha, "Sistem Informasi Manajemen Klinik Permata Medical Center Pati," no. April, pp. 733-739, 2015.

[11] Kementerian Kesehatan Republik Indonesia, PP Menteri Kesehatan Indonesia No. 92 tahun 2014. 2014, pp. 1-19.

[12] Kementerian Kesehatan Republik Indonesia, Peraturan Menteri Kesehatan Republik Indonesia Nomor 97 Tahun 2015 Tentang Peta Jalan Sistem Informasi Kesehatan Tahun 2015-2019. 2015, pp. 1-76.

[13] N. Awang Kalong and M. Yusof, "Waste in health information systems: a systematic review," Int. J. Health Care Qual. Assur., vol. 30, no. 4, pp. 341-357, 2017.

[14] E. Sumariani, "Analisis Kebutuhan Perencanaan Sistem Informasi Kesehatan pada Bidang Pelayanan Kesehatan Dinas Kesehatan Kabupaten Boyolali," Universitas Muhammadiyah Surakarta, 2015.

[15] E. S. Lestari, S. P. Jati, and A. P. Widodo, "Evaluasi Sistem Informasi Kesehatan di Provinsi Jawa Tengah Dalam Rangka Penguatan Sistem Informasi Kesehatan Nasional," $J$. Manaj. Kesehat. Indones., vol. 4, no. 3, pp. 222-231, 2016.

[16] P. E. Putro and B. K. Riasti, "Pembangunan Sistem Informasi Jaminan Kesehatan Rembang Sehat Berbasis Web Pada Dinas Kesehatan Kabupaten Rembang," vol. 3, no. 4, pp. 57-62, 2011. 